\title{
Korean EFL Learners' Perspectives on Speaking Tasks: Discussion, Summary, and Information-Exchange Tasks
}

\author{
Kim Mihye ${ }^{1}$ \\ ${ }^{1}$ Hankuk University of Foreign Studies, Korea \\ Correspondence: Kim Mihye, Hankuk University of Foreign Studies, 103-1105 Samik APT Shinmokro 16, \\ Yangchungu Seoul 158-820, Korea. E-mail: kim32mary@hanmail.net
}

Received: August 26, 2014 Accepted: September 30, 2014 Online Published: October 23, 2014

doi:10.5539/elt.v7n11p1 URL: http://dx.doi.org/10.5539/elt.v7n11p1

\begin{abstract}
This study investigates Korean university English as Foreign Language (EFL) learners' task preference among three different speaking tasks. Quantitative data were collected through questionnaires and qualitative data were collected from interviews. Quantitative datawere obtained from 88 survey respondents and qualitative data from 50 interview participants. Two sets of identical questionnaires were used before and after the semester in which the study took place. Learners were askedto rate their degrees of task preference and their levels of task interest and task satisfaction in the classroom. The results show that "Discussion task" is the most preferred task type among the three different speaking tasks: "Discussion task," "Information-exchange task," and "Summary task." However, learners report that "Information-exchange task" is the most difficult and their topic preference for the "Information-exchange task" is the lowest. In terms of the correlations between topic preference and speaking performance, moderate levels of positive correlations are shown. The findings suggest that task-based learningshould be widely utilized inuniversity-level EFL classrooms.
\end{abstract}

Keywords: learners' task-preference, task-interest and task-usefulness, learners' motivation, discussion task, summary task, information-exchange task

\section{Introduction}

Task-Based Language Teaching (TBLT) is considered an important teaching method in EFL classrooms, and several researchers have investigated the use of tasks in classrooms (Brown, 2004; Bygate, 1996; Ortega, 1999; Thornbury, 2005; Wendel, 1997; Wigglesworth, 1997). Within TBLT, speaking tasks are gaining popularity, and it is critical to understand task preference for university-level students among different task types. Task preference not only can motivate students' speaking performance but also reduce unnecessary time to explain irrelevant task types. Additionally, the goal of the university-level classroom is to meet students' expectation in class, so it is wise to use the most preferred task type to improve students' speaking performance in a limited time. Learners' perspectives have been largely ignored in the classroom implementation of different speaking tasks, such as "Discussion tasks," "Summary tasks," and "Information-exchange tasks." In studies considering the relationship between speaking tasks and learners' level, the perspectives and experiences of learners have been largely excluded while the central focus has been on teachers.

"Discussion task" is one of the most widely used methods of measuring learners' second language oral proficiency in language teaching (Hilsdon, 1991; Hohamy, Reves, \& Ejarano, 1986; Swain, 2001; van Lier, 1989; Young \& He, 1998). "Discussion task" can also be referred to as "Opinion-exchange task" because these two tasks permit a number of possible outcomes related to the topic (Ellis, 2003). An opinion gap (Samuda \& Bygate, 2008) involves the identification/articulation of personal preferences, attitudes, and/or responses to given information. Although more language teachers are using "Discussion tasks" to evaluate learners' speaking proficiency, only a small number of studies have carefully investigated the use of "Discussion tasks" as a test format (Bonk \& Ockey, 2003; Brooks, 2009; May, 2009; Swain, 2001).

In contrast, a "Summary task" is a controlled task and the outcomes may be different from the quality of the suggested passage. Though the "Summary task" has long been considered a critical pedagogical exercise (Dalgleish, 1988; Fielden, 1950; Seidlhofer, 1995), it has also been considered a necessary skill to acquire and develop in an EFL setting (Johns, 1988; Johns \& Mayes, 1990). However, no previous researchhas been conductedto validatethe "Summary task" as a measure of speaking competence among Korean EFL students. 
Several researchers have suggested that the "Information-exchange task" is a mechanical task that focuses on lexical items (Nakahaman, Tyler, \& van Lier, 2001; Newton, 1991). According to Newton (1991), there are two types of "Information-exchange tasks" that require information exchange and optional information exchange. He found that almost double the amount of negotiation was required for tasks where learners did not have equal access to the information provided when compared to tasks where the information was shared. Additionally, Nakahaman, Tyler, and van Lier (2001) found that although information-exchange tasks resulted in more negotiation and exchanges between learners, these tasksare still mechanical. In contrast, Varonis and Gass (1985) found that the interactions derived from a conversation task, where there was no required information exchange, resulted in greater negotiation of global problems, such as problems relating to anaphoric reference and interpretation of an entire utterance, significantly longer and more complex turns, and a wider use of discourse strategies, such as paraphrasing. The study focuses on a distinct task type, although all three different task types complement and build on each other.

\subsection{Research Questions}

Although several previous studies have examined speaking tasks and learners' preference, few studies have focused on university-level students, especially those in Korea. Therefore, this study provides useful information about choosing relevant speaking tasks foruniversity-level classrooms and may help teachers implementeffective speaking tasks in EFL settings. This study aims to determine whether any statistically significant relationshipsare present involving task preferencefor university students. Therefore, this study can assist teachers and program managers in choosing appropriate speaking tasks in EFL teaching contexts. The research questions for the present study are the following:

1) Do students display any task preference?

2) Do students report any task usefulness?

3) Do students report any task familiarity?

4) Do students report any classroom satisfaction?

5) What is the relationship between task preference and classroom satisfaction?

\section{Literature Review}

The role of tasks in an EFL curriculum has been debated for over 20 years. Willis (1996) argues that tasks should be the cornerstone of an EFL syllabus within a supportive framework that enables language development. This view represents the strong version of TBLT. However, in a task-supported approach, tasks are used to enrich the syllabus or to provide additional learning opportunities including online support and selective feedback (Brumfit, 1984; Bygate, 2000; Ellis, 2003; Nunan, 1995, 2001; Samuda \& Bygate, 2008; Ur, 1982). This study adopted a task-supported approach because the institution where the study was conducted did not permit whole-scale changes to the curriculum.

There are several task types that have been tested more directly through empirical research, such as information-gap tasks (Doughty \& Pica, 1986; Fotos \& Ellis, 1991; Yule \& McDonald, 1990), problem-solving tasks (Duff, 1986; Lynch, 1991), debate-style opinion exchanges (Duff, 1986), decision-making tasks (Brown, 1991; Foster \& Skehan, 1996), opinion-gap tasks (Ellis, 2003), and narrative tasks (Foster \& Skehan, 1996). This study examines three different types of speaking tasks: "Discussion tasks," "Summary tasks," and "Information-exchange tasks." Therefore, different speaking outcomes will be expected depending on each task type.

Ryoo (2010) conducted research on "Discussion tasks" as a method of testing oral proficiency. The participants in the study were Korean college-level EFL learners who were enrolled in regular academic course called "Current Topics in English." In this study, 17 students (12 females and 5 males) enrolled in the course, which dealt with a variety of societal issues with the purpose of improving students' overall English speaking proficiency. Ryoo adapted Galaczi's (2004) topic development moves, including "Topic Initiation," "Self-Topic-Build," "Minimal-Acknowledgement," "Topic Recycling," "Topic Extension," and "Topic Close." According to her research, the learners' discussions did not show much evidence of the collaborative interactional patterns thatare positively valued in speaking-proficiency assessment. Rather, the interactions the learners had in this study were mostly disjointed and discontinued, lacking connected thoughts and ideas, which can be a debilitating factor in the evaluation of their oral proficiency. Ryoo'sresearch purpose overlaps with that of the present study because both studies examine university-level students in Korea.

Haemoon, Heesoo, and Yousook (2007) studied the use of summary tasks. They found that argumentative texts 
resulted in more complex interlanguage (IL) but expository texts resulted in more accurate IL, without a difference in fluency, and summary quality did not change by text type or repetition. In this study, there were 6 summarizers and 18 hearers. The summarizers were allfirst-year students at a large university in Seoul who were enrolled in an intensive English program at the university language institute. The hearers were also intermediate-level students chosen randomly from the same program. Each summarizer summarized the same text to three different hearers repeatedly. This present study adapts Haemoon et al.'s (2007) idea that the quality of learners' performance may not change across text type.

George (2014), using a CA framework, highlights learners' interactional practices with a primary focus on repairs and word searches to show how opportunity for learning arises in the task, while also highlighting the sequences that arise in and around the repair, such as counter questioning, designedincomplete utterances, and explicit positive assessment. The data gathered for analysis were collected from a non-compulsory, high-intermediate English language conversation/discussion class at the language institute of a university in Seoul.

There are guidelines for conducting the three types of tasks in the classroom. First, for "Discussion tasks," learners are givena specific topic to think about. The topics mainly deal with controversial ideas such as "thoughts on plastic surgery" and "comparing cars and bicycles for transportation usage." Second, for "Summary tasks," learners are givena specific reading passage, with the exception of one learner who is the presenter. Group members summarize the reading passage and the presenter collects other group members' summaries. The presenter makes a presentation using the other members' summaries at the end of the class. Third, for "Information-exchange tasks," every group member hasthe same reading passage except for one presenter. The presenter asks the other members questions about the reading passage. The presenter makes a presentation using the information that the other group members provided.

In the present study, these three different speaking tasks were used. All tasks were monologues thereby avoiding issues related to interaction (Storch, 2002). The present study analyzes learners'interviews to understand the specific reasons for their task preference and classroom satisfaction. The details of the procedure are provided in the methodology section.

In the current literature, there is a lack of empirical studies examining Korean learners' collected opinions on task preference. Therefore, the present study has both theoretical and practical value in terms of the implementation of a learner-centered curriculum and the encouragement of learner participation in evaluation materials, which may result in more effective decisions regardingtask preference.

\section{Research Design and Method}

\subsection{Research Design}

This study addresses the research questions by asking 88 learners atone university in Korea to rate task preference on a questionnaire, and by conducting interviews with 50 learners about what task they find important when considering speaking improvement. This study was conductedduringone semester, from March to July in 2008, in a two-credit Business class that was taught by the researcher. The students met once a week for two hours for 16 weeks. During the semester, three different speaking tasks (information-exchange, summarization, and discussion) were conducted. The researcher collected students' questionnaires and analyzed their answers.

Examples of each task are presented below.

1) Summary task

Since the learners were enrolled in a course on"Economics and English," they were required to read articles related to the economy. Each small group went through the summary process regarding the content. After conducting the summary process, only one presenter gave a presentation about the given topic. An example of a summary presentation is presented below.

Our group summarizes that the Korean trade exhibition, in comparison to China, has a language barrier and is under-prepared for the market studies. So, Korea isn't attractive for buyers and Chinese participants. China, because of its economic prospects, has a convenient geographical location and industrial benefits, which makes it too difficult for us to challenge. Um, as for Shanghai, the headquarters from Hong Kong are moving to Shanghai because their manufacturing sites are well situated and buyers want to show how the factories are managed and operated.

In this example, students' speaking accuracy was relatively high since they have the key words and the meaning of the whole paragraph before they start speaking. The results of the questionnaire show that students were able 
to lower their anxiety since they were able to use the suggested key words. Lower levels of anxiety helped students to increasetheir motivation levels.

2) Information-exchange task

In this task, one of the members in a small group leaves and the other members received information about the given topic. The presenter can organize the information by askingthe other members questions about the given information. In order to determine the contents, the other group members had to answerthe questions using the given information. An example from this task is shown below.

This paragraph tells how marketing and selling concepts are important. Um...because these concepts can persuade consumers to buy, even though they don't think that it's essential. Also, not only existing needs but also services could be newly created. That's all.

This example shows that students' have a difficult time getting the information through asking questions. This presenter had a lot of anxiety about having to ask questions from scratch. Therefore, students' speaking fluency in this task was relatively low compared to the other two tasks.

3) Discussion task

Each small group talked about the different topics and debated with each other for 20 minutes. After the discussion time, the presenter announced the group's opinions about the given topic. An example of the discussion task is presented below.

We.... we discussed about, ah, we discussed foreign advertisements and Korean advertisements. First, the foreign advertisements have the uh, they ...advertise a product by comparing itto other rival products specifically. For example, consider the Pepsi and Coca-Cola advertisements. Ah, and the advertisement, Pepsi advertises their fancy truck abut uh.... uh.... uh.... oppo. Uh...opposing their .... uh, in, oppose (opposition) to the Coca-Cola's truck, their Coca-Cola's truck was uh, it seemed very dirty. And they directly advertised...uh the Pepsi's quality of their (by) ah, showing the, their truck. Um...and they, in the, in this advertisement older people can appear rather than celebrities.

And...they tend to show the evidence of quality by...um, experiments. Um, and (in) Korea's advertisements, products are shown more visually and directly other (rather) than descripting (describing) the products, comparing them with other products. And comparing with other products directly ah, it is not allowed in Korea. Um ... Andcele, famous celebrities are used as models and (for a) very expensive model fee. Um, ah. We had the conclusion ah, to have a ...good advertisement ah, that just stimulates the consumers by showing the focus on quality and allowing the products to be compared with the rival product directly.

In this example, students' task preference for "Discussion task" was very high, and this influenced their speaking fluency level. However, students' speaking accuracy for "Discussion task" was relatively low because they had to integrate their inner knowledge in order to express their opinion on the topic. Students' complexity level was also higher in this task than the other two tasks.

\subsection{Subject Characteristics}

The subjects in this study were 88 students enrolled in a business class at a university in Korea. Among them, 30 $(34.1 \%)$ were male and $58(65.9 \%)$ were female. The gender distribution seems to be similar across the courses. There were 52 students who were majoring English (59.1\%) and 36 who were majoring in other subjects $(40.9 \%)$. The number of students who had experience living in English-speaking countries was 54 (61.4\%), and the number of students who had no experience living in English-speaking countries was 34 (38.6\%). The number of students who displayed a task preference for "Summary task" was 21 (23.9\%), "Information-exchange task" was $10(11.4 \%)$, and "Discussion task" was 57 (64.8\%).

Table 1. Subject characteristics

\begin{tabular}{llll}
\hline Items & & $\mathrm{N}$ & Percent (\%) \\
\hline \multirow{3}{*}{ Gender } & Male & 30 & 34.1 \\
\cline { 2 - 4 } & Female & 58 & 65.9 \\
\cline { 2 - 4 } & Total & 88 & 100.0 \\
\hline Major & Other major & 36 & 40.9 \\
\hline
\end{tabular}




\begin{tabular}{|c|c|c|c|}
\hline & English major & 52 & 59.1 \\
\hline & Total & 88 & 100.0 \\
\hline \multirow{3}{*}{$\begin{array}{l}\text { Do you have any experience living in } \\
\text { English-speaking countries? }\end{array}$} & No experience & 34 & 38.6 \\
\hline & Experience & 54 & 61.4 \\
\hline & Total & 88 & 100.0 \\
\hline \multirow{4}{*}{$\begin{array}{l}\text { Which of the task styles do you prefer: } \\
\text { summary tasks, information-exchange } \\
\text { tasks, or discussion tasks? }\end{array}$} & Summary task & 21 & 23.9 \\
\hline & Information-exchange task & 10 & 11.4 \\
\hline & Discussion task & 57 & 64.8 \\
\hline & Total & 88 & 100.0 \\
\hline
\end{tabular}

\subsection{Questionnaire}

Two sets of identical questionnaires, which asked about the interest and usefulness ofthe topics and subjects' motivational orientations, were used before and afterthe speaking task took place in the classroom. Ratings on task interest and task-usefulness, task-familiarity, and classroom satisfaction were provided using a seven-point Likert-scale on which 1 is equal to not atall interesting (useful) and 7 is equal to extremely interesting (useful). For each item, to avoid forced responses, a scale for "not sure" was included. The samplequestionnaire used at the end of the course is presented in the Appendix. Theindividual items for the topics are presented in the tables showingthe results inthe following section.

In terms of asking about motivational orientation, the learners were requestedto rate how far they agreed on the importance of each of the eight items. Theitems were adapted from the Attitude Motivation Test Battery from Gardner (1985). Item 1 was Speaking English is easy for me. Item 2 was I want to improve my English ability. Item 3 was I want to improve my speaking ability. Item 4 was what task do you prefer? Item 5 was What task is more helpful for improving your speaking ability? Item 6 was what task are you familiar with? Item 7 was through the tasks, my motivation was improved. Item 8 wasWhen you speak English, do you translate Korean into English? and Item 9 wasIt will enable me tobetter understand and appreciate other countries' art and literature. The itemsreflected whether students felt that this kind of speaking class is helpful. Ratings were given using a7-point Likert-scale on which 1 equals fully disagree and 7 equals fully agree. Thequestionnaires were administered on the first and last classes by theclassroom teachers. It took about 10 minutes for the respondents toanswer all the items. To estimate the reliability of the eight items representing motivationalorientation, Cronbach's alpha was used. For each questionnaire, Cronbach's alpha was separately computed because the topic-itemswere different across the questionnaires. The results showed that $\alpha=.66$, which indicated an acceptable level of itemreliability. A low level of reliability was found for the first questionnaire for course C, namely $\alpha=.32$, which wasprobably caused by the small number of respondents $(n=7)$. However, it was concluded that the items were acceptably reliable for therespondents in the present study.

Data collection was carried outfor one semester in 2008. SPSS 12.0 and ANOVA were used for analysis. For analysis of the quantitative data, descriptive statistics, factor analysis, correlation analysis, and t-testswere conducted. The quantitative data were categorized by task preference and presented on the basis oflearners' answers for taskpreference.

\section{Results}

\subsection{Quantitative Findings}

1) Do the students display any task preference?

An ANOVA test was performed to check learners' perception of the different tasks. After conducting the ANOVA test, a post-hoc testwas conducted to prove the statistical difference for each task type. Then, Duncan's multiple range test was done to prove the post-hoc results for this study and the mean difference was identified as $\mathrm{H}$ (High), $\mathrm{M}$ (Medium), and L (Low).

In terms of the task preference for the three different task types, the mean score for "Summary task" was 3.34, the mean score for "Information-exchange task" was 3.51, and the mean score for "Discussion task" was 3.69. The F value was 3.23 and the significance level (alpha) was 0.041 . Therefore, the resultsare statistically 
meaningful. The results show that "Discussion task" was the highest followed by "Information task" and "Summary task."

Table 2. Degree of helpfulness of the tasks

\begin{tabular}{llll}
\hline Items & $\mathrm{N}$ & Mean & SD \\
\hline Summary task & 88 & 3.34 & 0.86 \\
Information task & 88 & 3.51 & 0.80 \\
Discussion task & 88 & 3.69 & 1.08 \\
\hline
\end{tabular}

Note. ${ }^{*} \mathrm{p}<0.1 * * \mathrm{p}<.05 * * * \mathrm{p}<0.01$

The reason for the high preference for "Discussion task" was that there was no regulation on learners' speaking during this task. Learners could express any ideas on the topic, and they could use their previous knowledge on the topic. Especially for high-levellearners, the "Discussion task" was effective for improving their speaking ability.

2) Do the students report any task usefulness?

For the questionnaire item Which task do you think the most useful? "Discussion task" was the most useful task followed by "Summary task" and "Information-exchange task." The mean score for "Discussion task" was 4.08, "Summary task" was 3.66, and "Information-exchange task" was 3.63. Table 3 shows the results.

Table 3. Degree of task usefulness

\begin{tabular}{llll}
\hline Items & $\mathrm{N}$ & Mean & $\mathrm{SD}$ \\
\hline Summary task & 88 & 3.66 & 0.91 \\
Information task & 88 & 3.63 & 0.82 \\
Discussion task & 88 & 4.08 & 0.78 \\
\hline
\end{tabular}

Note. ${ }^{*} \mathrm{p}<0.1 * * \mathrm{p}<.05 * * * \mathrm{p}<0.01$

According to the results, the most useful speaking task type was "Discussion task." Since most students were preparing for job interviews after graduation, they felt that "Discussion task" was the most useful. In fact, the "Discussion task" type is the most frequently used speaking task in Korean EFL settings.

3) Do the students report any task familiarity?

The statistical results for task familiarity showed that the "Discussion task" type was the most familiar of the three speaking task types. The mean score for "Discussion task" was 3.43, "Summary task" was 3.36, and "Information task" was 3.28. Table 4 shows the result of learners' task familiarity.

Table 4. Degree of helpfulness of the tasks

\begin{tabular}{llll}
\hline Items & $\mathrm{N}$ & Mean & $\mathrm{SD}$ \\
\hline Summary task & 88 & 3.36 & 0.87 \\
Information task & 88 & 3.28 & 0.86 \\
Discussion task & 88 & 3.43 & 1.04 \\
\hline
\end{tabular}

Note. ${ }^{*} \mathrm{p}<0.1 * * \mathrm{p}<.05 * * * \mathrm{p}<0.01$

Learners were most familiar with "Discussion task" because of their previous experience in classroom. The most frequent task type in English-speaking classes is "Discussion task" or "Debate opinion-exchange task." 
4) What is therelationship between task types and classroom satisfaction?

To determine the statistical results for task preference and classroom satisfaction, a multiple-regression test was done. The F-value of the ANOVA table was 5.40 and the p-value was 0.01. Therefore, a regression test was valid. Among the three different tasks, the preference for "Discussion task" influences classroom satisfaction positively. The preference for "Summary task" or "Information-exchange task" does not influence classroom satisfaction positively. Therefore, only the preference for "Discussion task" influences classroom satisfaction. Table 5 shows the results.

Table 5. Task preference and classroom satisfaction

\begin{tabular}{|c|c|c|c|c|c|c|c|}
\hline & \multicolumn{2}{|c|}{$\begin{array}{l}\text { Unstandardized } \\
\text { Coefficients }\end{array}$} & \multirow{2}{*}{$\begin{array}{l}\text { Standardized } \\
\text { Coefficients }\end{array}$} & \multirow[t]{2}{*}{$\mathrm{t}$} & \multirow[t]{2}{*}{ Sig. } & \multicolumn{2}{|l|}{$\begin{array}{l}\text { Collinearity } \\
\text { Statistics }\end{array}$} \\
\hline & $\bar{B}$ & Std. Error & & & & Tolerance & VIF \\
\hline (Constant) & 3.23 & 0.36 & & 9.00 & 0.000 & & \\
\hline I like summary tasks. & -0.08 & 0.10 & -0.099 & -0.79 & 0.434 & 0.62 & 1.60 \\
\hline I like information tasks. & 0.14 & 0.11 & 0.161 & 1.32 & 0.191 & 0.67 & 1.50 \\
\hline I like discussion tasks. & 0.24 & 0.07 & 0.364 & 3.26 & $0.002^{* * *}$ & 0.80 & 1.25 \\
\hline
\end{tabular}

Note. Dependent Variable: I think that speaking in class is helpful.

${ }^{*} \mathrm{p}<0.1 * * \mathrm{p}<.05 * * * \mathrm{p}<0.01$

According to the results, most university students prefer "Discussion task" and their task preference influences "classroom satisfaction." This result shows that university students' cognitive preference and speaking performance are related.

5) What is the relationship between the degree of helpfulness of a speaking task and classroom satisfaction?

Among the three different tasks, "Discussion task" has a positive influenceon classroom satisfaction depending on the degree of help for the task. According to the statistical results, the t-value was 2.75 and the p-value was 0.007 . Therefore, the results are statistically significant.

For "Summary task," the t-value was -0.19 and the p-value was 0.847 . Therefore, the results show that the degree of classroom help does not affect classroom satisfaction positively. For "Information-exchange task,"the $\mathrm{t}$-value was 1.55 and the p-value was 0.126 . Therefore, the result was not statistically significant. That is, "Information-exchange task" does not influence classroom satisfaction positively. According to the results, "Discussion task" helps the learners the most in the classroom. Table 6 shows the results.

Table 6. Degree of helpfulness of the tasks

\begin{tabular}{lllllll}
\hline & \multicolumn{2}{l}{$\begin{array}{l}\text { Unstandardized } \\
\text { Coefficients }\end{array}$} & \multicolumn{2}{l}{$\begin{array}{l}\text { Standardized } \\
\text { Coefficients }\end{array}$} & \multirow{2}{*}{ Sig. } \\
\cline { 2 - 5 } & $\mathrm{B}$ & \multicolumn{2}{l}{ Std. Error } & Beta & & \\
\hline (Constant) & 2.56 & 0.42 & & 6.03 & 0.000 \\
\hline Summary tasks help my speaking ability. & -0.02 & 0.11 & -0.028 & -0.19 & 0.847 \\
\hline Information tasks help my speaking ability. & 0.21 & 0.13 & 0.240 & 1.55 & 0.126 \\
\hline Discussion tasks help my speaking ability. & 0.27 & 0.10 & 0.297 & 2.75 & $0.007^{* * *}$ \\
\hline F $=6.61$, Sig. $=0.000$, R Square $=0.19$ & & & & & \\
\hline
\end{tabular}

Note. Dependent Variable: I think that speaking in class is helpful.

$* \mathrm{p}<0.1 * * \mathrm{p}<.05 * * * \mathrm{p}<0.01$ 
According to the statistical results above, the findings were statistically significant. Thus, for the participants who think the task types are helpful, their speaking performance is improved. This dynamic occurred because the learners' positive cognitive attitudestoward the task type influence their speaking performance.

6) What is the relationship between task familiarity and classroom satisfaction?

The results from themultiple-regression test show that there is the relationship between task familiarity and classroom satisfaction. The regression model has validity since the $\mathrm{F}$ value in the ANOVA table was 0.040 .

Among the three different tasks, "Discussion task" has apositive influence on classroom satisfaction. The t-value was 2.76 and the p-value was 0.0007 . Therefore, the test result was statistically significant. The "Summary task" also positively influenced classroom satisfaction. However, there was no statistical significance for the "Information-exchange task." Table 7 shows the results.

Table 7. Task familiarity and classroom satisfaction

\begin{tabular}{|c|c|c|c|c|c|}
\hline & \multicolumn{2}{|c|}{$\begin{array}{l}\text { Unstandardized } \\
\text { Coefficients }\end{array}$} & \multirow{2}{*}{$\begin{array}{l}\text { Standardized } \\
\text { Coefficients } \\
\text { Beta }\end{array}$} & \multirow[t]{2}{*}{$\mathrm{t}$} & \multirow[t]{2}{*}{ Sig. } \\
\hline & $\mathrm{B}$ & Std. Error & & & \\
\hline (Constant) & 3.79 & 0.33 & & 11.60 & 0.000 \\
\hline Summary task & -0.04 & 0.12 & -0.050 & -0.33 & 0.739 \\
\hline Information-exchange task & -0.04 & 0.13 & -0.046 & -0.30 & 0.762 \\
\hline Discussion task & 0.24 & 0.09 & 0.348 & 2.76 & $0.007^{* * *}$ \\
\hline \multicolumn{6}{|c|}{$\mathrm{F}=2.90$, Sig. $=0.040, \mathrm{R}$ Square $=0.29$} \\
\hline
\end{tabular}

One explanation for these results is that the learners' task familiarity influences their speaking performance. When the learners are familiar with the task type, the teachers can expect better speaking performance in the classroom.

\subsection{Qualitative Findings}

In addition to the quantitative data, qualitative data were also collected and analyzed. Fifty students were interviewed and asked to give their opinions on their most preferred task. The opinions collected are considered representative of the students' insights regarding speaking tasks in the classroom in light of their previous learning experiences. The interviewees' responses were coded and grouped into four relevant categories for the qualitative analysis. Even though the intervieweeswere not informed of the four relevant categories before the interview, their comments fit the overall analysis. The findings show that the majority of learners are especially interested in task-based language teaching for their speaking classes, and the task they prefer the most is the "Discussion task." Examples from the students' responses to the questions in the interviews are presented below.

Q1: Write down your general ideas about this class.

Most students held positive views about the class. Overall, they thoughtthat this type of class is a very effective way to improve their English ability. Some of the positive and negative comments are shown below.

Positive comments:

I learned many things about the speaking tasks that I didn't know before.

I was able to give feedback to group members.

I had a chance to correct my pronunciation after getting feedback from other group members.

It was really fun to speak (speaking task) together with the different tasks. It was like a fun game.

I could compare my speaking to other group members, which made me more aware of my speaking.

The classroom procedures such as presentations, group discussions, and assignments were really good.

The discussion about the topics in a group was really fresh and new for me.

While we are participating in group work, we can give each other feedback. 
The assignment (recording) was useful.

I feel that I could understand the different speaking tasks.

Negative comments:

The time for group discussion was short. So, we can't get rich feedback about our opinions from the teacher. I want to know whether my overall speech is correct or not.

I wished that I could get feedback about my recording assignment more accurately.

Q2: What do you think about the "Discussion task"?

In their responses, more than $50 \%$ of students answered "Interesting" for this question, and $3 \%$ answered "Helpful." The number of students who did not strongly like or dislikethe "Discussion task" was 11 (25.5\%), and six students responded that they did not like the "Discussion task" (13.9\%). These results are shown in Table 8 . Examples from students' comments are presented below.

Table 8. Perceptions of the "discussion task"

\begin{tabular}{ll}
\hline Interesting & $23(53.4 \%)$ \\
Helpful & $3(6.9 \%)$ \\
So-So & $11(25.5 \%)$ \\
Dislike & $6(13.95 \%)$ \\
\hline
\end{tabular}

Example responses for "Interesting"

Before conducting each task in a small group, I was able to understand the "Discussion task" easily. However, the "Information gap task" was difficult to understand.

After conducting the "Discussion task," I could talk about the topic easily. Therefore, while conducting the "Discussion task," I felt that my anxiety was reduced.

After completing the "Discussion task" in the classroom, I was able to use more vocabulary words and expressions to express my ideas on the topics. I could even speak for a longer time in conversations.

While I was doing an assignment at home, I was able to think about the topics more deeply and correct wrong expressions by myself.

After conducting the "Discussion task," I had several opportunities to talk about different topics. I had confidence to speak in English, so my anxiety about expressing my opinions on the topic was lowered.

Before I conducted the "Discussion task," I was always worried about expressing my ideas on the topics. However, after sharing ideas with group members and finishing my assignments, I have more confidence to express my ideas.

Example responses for "Helpful"

After finding out what the "Discussion task" is, I feel that the "Discussion task" helps for any kind of interview.

The "Discussion task" is helpful for me to think deeply on every topic.

Example response for "So-So"

The "Discussion task" had no influence on improving my speaking ability.

Q3: What do you think about the "Summary task"?

For this question, more than $60 \%$ of the students said that the "Summary task" is interestingwhile $2 \%$ of the students said that the task was helpful. Table 9 shows the results, and examples from the students' comments are presented below. 
Table 9. Perceptions of the "summary task"

\begin{tabular}{ll}
\hline Interesting & $29(67.4 \%)$ \\
Helpful & $1(2.3 \%)$ \\
So-So & $13(30.2 \%)$ \\
\hline
\end{tabular}

Example responses for "Interesting"

I was able to improve my summarizing skills through the "Summary task."

The "Summary task" is useful for both speaking and writing skills.

I could improve my confidence using the "Summary task" since I was able use the suggesting reading passage before speaking about the topic.

Even though I was supposed to speak about something during anunfamiliar task, I feel that my speaking skills have improved because I can use a variety of vocabulary words in the reading passage.

I had confidence in small groups in class, and my confidence will be improved in the long term.

Example responses for "Helpful"

The "Summary task" will help me improve my summary skills.

The "Summary task" is helpful to sum up the meaning of the passage using essential key words.

Example responses for "So-So"

I don't think "Summary task" is helpful for my speaking ability.

When the reading passage is difficult, it is hard to summarize the passage.

Q4: What do you think about the "Information-exchange task"?

For the "Information-exchange task," $81 \%$ of the students answered that this task affects their speaking ability and they found it to be an interesting task. The students were hesitant before conducting the "Information-exchange task" because most were not familiar with the task. Table 10 shows the results for this question, and some of their commentsare presented below.

Table 10. Perceptions of the "Information-exchange task"

\begin{tabular}{ll}
\hline Interesting & $35(81.3 \%)$ \\
Helpful & $5(11.6 \%)$ \\
So-So & $3(6.9 \%)$ \\
\hline
\end{tabular}

Example responses for "Interesting"

Actually, I have not tried the "Information-exchange task" in the classroom. However, it is like a game.

I can improve both asking and answering skills using the "Information-exchange task."

The reason is that I could listen to other students' opinions and learn from someone who has a good English proficiency. I think that I could learn kinds of studying strategies to improve my speaking.

If we hadmore feedback, it would be more effective.

Example response for "Helpful"

If the group leader has a high speaking proficiency, the "Information-exchange task" would be helpful to talk about the passage.

Example responses for "So-So"

I have to rely totally on the answers to get the idea. If the answer is wrong, I cannot understand the correct meaning of the passage.

The "Information-exchange task" has no merits.

The "Information-exchange task" is so ambiguous and it tasks too much time to get the meaning of the passage 
before speaking.

Q5.1: What do you expect your speaking ability to be when this semester is finished?

About $90 \%$ of the students said that they expect their speaking ability to improve when this semester is finished, while only five students answered that they expected their speaking to be worse. After 10 weeks of class, many students are confident enough to talk to somebody, and their responses indicated that they expect to have improved speaking abilities after the semester. Table 11 presents the results, and examples from their comments are shown below.

Table 11. Expectations of speaking ability

\begin{tabular}{ll}
\hline Speaking will be better. & $38(88.3 \%)$ \\
Speaking will be worse. & $5(11.6 \%)$ \\
So-So & $0(0 \%)$ \\
\hline
\end{tabular}

Example responses for "Speaking will be better"

My sense of talking about the several topics will be rich. Especially, when I have a chance to address my idea, this kind of class will be useful for me.

I have a chance to use the words that I am not using in daily life when I talked about the topics by discussion task.

If I do my best more, I will easily pass English interviews for a job. *

Because I talk about the topic in a small group consciously and then upload my idea, I could feel that my speaking ability will be better. *

Absolutely it will be improved but make sure when I do my best.

Example response for "So-So"

There will be no difference.

Q5.2: How do you expect your speaking ability to develop if you continue to have this style of class?

This question asked students about their long-term expectations of how their speaking ability will develop with this type of class. Most students reported that they expect their speaking ability will improve in the long term; however, one of them predicted their speaking ability woulddecline. Task-based classroom instruction made them more confident and less anxious, which led to them having more chances to participate in speaking practice. Table 12 presents the results for this question, and examples from the students' responses are shown below.

Table 12. Expectations of long-term speaking ability

\begin{tabular}{ll}
\hline Speaking will be better. & $41(95.3 \%)$ \\
Speaking will not be better. & $1(2.3 \%)$ \\
So-So & $1(2.3 \%)$ \\
\hline
\end{tabular}

Example responses for "Speaking will be better"

Not only grammatical accuracy but also my ability to express my thoughts will be improved.

Sharing opinions on the topic in small groups helps lower anxiety in this class, so this will improve my speaking ability.

I will get used to the concept of task-based language teaching. Then, I will be able to speak about any topics with confidence.

If I continue to take this kind of class in the long term, my confidence will increase.

Response for "Speaking will be worse"

I don't think that this kind of class will be effective for my speaking ability. 
Response for "So-So"

I have many problems with sentence structure and speaking ability. So, I'm not sure whether this class will be helpful.

\section{Discussion}

For the item I think that speaking in class is helpful, there was no influence on "Summary task" and "Information task." However, there was a positive influence of "Discussion task" on classroom satisfaction. In terms of the statistical results for this item, the alpha score for I like discussion tasks was 0.36 , which means that when the learners like task, it influences classroom satisfaction. However, the alpha score for the item I like information tasks was 0.161 and I like summary tasks was 0.099 . Therefore, I assume that the "Summary task" influence on classroom satisfaction was the lowest.

When comparing the relationship between task help and classroom satisfaction, "Discussion task" has the highest influence for helping learners' speaking ability. For the itemDiscussion tasks help my speaking ability, the alpha value was 0.297 , and it showed the highest influence for helping the learners. In addition, the alpha value for Information tasks help my speaking ability was 0.240 and Summary tasks help my speaking ability was -0.028 . Therefore, I assume that the learners' perception for task help influences positively their speaking ability.

Overall, the study results show that when the learners are familiar with the tasks, their classroom satisfaction increases. For "Summary task" and "Information-exchange task," these two tasks do not influence learners' classroom satisfaction. However, for "Discussion task," learners showed a high level of satisfaction with the class. In addition, "Discussion task" has the highest influence rate for the class followed by "Summary task" and "Information-exchange task."

\section{Conclusion}

This study investigated Korean university students' task preference in an EFL classroom. The investigated tasks were "Discussion task," "Summary task," and "Information-exchange task." The study results revealed that the most preferred task for these university students is "Discussion task," followed by "Information task." The "Summary task" was the least preferred. Moreover, a difference was found for participants' perceptions regarding the most helpful task for their speaking ability. According to their answers on the questionnaire, "Discussion task" was found to be the most helpful, followed by "Summary task" and "Information-exchange task."This study also found that tasks that are appropriate for language learners' level can help learners improve their language skills in the classroom. When the tasks are too difficult for language learners, it is not easy to perform the task in the classroom, and the process becomes time consuming. However, when the teacher chooses the most preferred task for language learners, their speaking abilities can easily improve.

The findings of this study have potential implications for language teaching. First, teachers should carefully consider different aspects of tasks so that learners can easily perform their language task in the classroom. Second, the "Discussion task" contains several language procedures. There are many opportunities to tailor the "Discussion task" to learners' diverse needs in terms of speaking abilities. In other words, the "Discussion task" provides teachers the opportunity to fit the task to the specific needs of the learners. Third, teachers should modify traditional tasks for the EFL classroom. Not all the tasks are appropriate for EFL classrooms because these students have different cultures and different ways of thinking. Therefore, teachers should be flexible and modify the traditional tasks to suit each language-teaching classroom.

The study described in this paper has several limitations. Despite the fact that many tasks were considered efficient for language teaching in classroom, sometimes the participants had difficulties in understanding the task that the teacher wanted them to perform. When designing the classroom syllabus, course designers are advised to consider the level of the students in advance and choose appropriate tasks. I found the decision-making tasks are the most preferred speaking task in the university-level classroom. However, I did not find that the "Discussion task" was more preferable than the decision-making task. These shortcomings suggest that more speaking topics should be included in the classroom, even for a "Discussion task." In addition, diverse speaking tasks to enhance learners' abilities should be created.

\section{Acknowledgements}

This paper is assisted by Ms. Merilee, a teacher at the Hankuk University of Foreign Studies. I appreciate her help.

\section{References}

Bonk, W. J., \& Ockey, G. J. (2003). A many-facet Raschanalysis of the second language group oral discussion 
task. Language Testing, 20(1), 89-110. http://dx.doi.org/10.1191/02655322031t245oa

Brooks, L. (2009). Interacting in Paris in a test of oral proficiency: Co-constructing a better performance. Language Testing, 26(3), 341-366. http://dx.doi.org/10.1177/0265532209104666

Brown, H. (2004). Language assessment: Principles and classroom practices. White Plains, NY: Pearson Education.

Brown, R. (1991). Group work, task difference, and second language acquisition. Applied Linguistics, 12, 1-12. http://dx.doi.org/10.1093/applin/12.1.1

Brumfit, C. J. (1984). Communicative methodology in language teaching. Cambridge: Cambridge University Press.

Bygate, M. (2000). Introduction to special issue: Tasks in language pedagogy. Language Teaching Research, 4(3), 185-192. http://dx.doi.org/10.1177/136216880000400301

Bygate, M. (1996). Effects of task repetition: Appraising the developing language of learners. In J. Willis, \& D. Willis (Eds.), Challenge and change in language teaching (pp. 36-46). London: Heinemann.

Dalgleish, W. S. (1988). Introductory textbook of English composition: Based on grammatical synthesis, with appendices treating of figures of language and prosody. Halifax, Nova Scotia: A \& W Mackinlay.

Doughty, D., \& Pica, T. (1986). Information-gap tasks: Do they facilitate second language acquisition? TESOL Quarterly, 20, 305-324. http://dx.doi.org/10.2307/3586546

Duff, P. A. (1986). Another look at interlanguage talk: Taking task to task. In R. Day (Ed.), Talking to learn (pp. 147-181). Rowley, Mass: Newburg House.

Ellis, R. (2003). Task-based language learning and teaching. Oxford: Oxford University Press.

Fielden, F. J. (1950). A guide to précis-writing. London: University Tutorial Press.

Foster, P., \& Skehan, P. (1996). The influence of planning and task type on second language performance. Studies in Second Language Acquisition, 18, 299-323. http://dx.doi.org/10.1017/S0272263100015047

Fotos, S., \& Ellis, R. (1991). Communicating about grammar: A task-based approach. TESOL Quarterly, 25(4), 605-628. http://dx.doi.org/10.2307/3587079

Gardner, R. C. (1985). Social psychology and second language learning: The role of attitudes and motivation. London: Edward Arnold.

Galaczi, E. (2004). Peer-peer interaction in a paired speaking test: The case of the first certificate in English (Ph.D. dissertation, Columbia University Teachers College).

George, S. (2014). Opportunities for learning: Teacher-student and student-student interaction in an information gap task. Modern English Education, 15(1), 49-70.

Hilsdon, J. (1991). The group oral exam: Advantages and limitations. In J. C. Alderson, \& B. North (Eds.), Language testing in the 1990s (pp.189-197). London: Modern English Publications and the British Council.

Haemoon, L., Heesoo, P., \& Yousook, Y. (2007). The effects of repeated oral summarization on the learners' IL performance and summary quality. Korean Journal of Applied Linguistics, 23(2), 125-146.

Lynch, T. (1991). Questioning roles in the classroom. ELT Journal, 45(3), 201-210. http://dx.doi.org/10.1093/elt/45.3.201

Johns, A. M. (1988). Reading for summarizing: An approach to text orientation and processing. Reading in a Foreign Language, 4(2), 79-90.

Johns, A. M., \& Mayes, P. (1990). An analysis of summary protocols of university ESL students. Applied Linguistics, 11(3), 253-271. http://dx.doi.org/10.1093/applin/11.3.253

May, L. (2009). Co-constructed interaction in a paired speaking test: The rater's perspective. Language Testing, 26(3), 397-421. http://dx.doi.org/10.1177/0265532209104668

Nakahama, Y., Tyler, A., \& van Lier, L. (2001). Negotiation of meaning in conversational and information-gap activities: A comparative discourse analysis. TESOL Quarterly, 35, 377-405. http://dx.doi.org/10.2307/3588028

Newton, J. (1991). Negotiation: Negotiating what? Paper given at SEAMEO Conference on Language Acquisition and the Second/Foreign Language Classroom, RELC, Singapore. 
Nunan, D. (2001). Expressions. Boston, MA: Heinle \& Heinle.

Nunan, D. (1995). Atlas: Learning-centered communication. Boston, MA: Heinle \& Heinle.

Ortega, L. (1999). Planning and focus on form in L2 oral performance. Studies in Second Language Acquisition, 21, 109-148. http://dx.doi.org/10.1017/S0272263199001047

Ryoo, H. K. (2010). Discussion task as a method of oral proficiency test: Responding to the others. The Journal of Linguistic Science, 55, 29-50.

Samuda, G., \& Bygate, M. (2008). Tasks in second language learning. Basingstoke: Palgrave Macmillan.

Seidlhofer, B. (1995). Approaches to summarization: Discourse analysis and language education. Tubingen: Gunter Narr.

Shohamy, E., Reves, T., \& Bejarano, Y. (1986). Introducing a new comprehensive test of oral proficiency. ELT Journal, 40, 212-220. http://dx.doi.org/10.1093/elt/40.3.212

Storch, N. (2002). Patterns of interaction in ESC pair work. Language Learning, 52(1), 119-158. http://dx.doi.org/10.1111/1467-9922.00179

Swain, M. (2001). Examining dialogue: Another approach to content specification and to validating inferences drawn from test scores. Language Testing, 18(3), 275-302.

Thornbury, S. (2005). How to teach speaking. Harlow, Essex: Pearson Longman.

Ur, P. (1982). Discussions that work. Cambridge: Cambridge University Press.

Van Lier, L. (1989). Reeling, writhing, drawing, stretching, and fainting in coils: Oral proficiency interviews as conversations. TESOL Quarterly, 23, 480-508. http://dx.doi.org/10.2307/3586922

Varonis, E., \& Gass, S. (1985). Non-native/non-native conversations: A model for negotiation of meaning. Applied Linguistics, 6, 71-90. http://dx.doi.org/10.1093/applin/6.1.71

Wendel, J. (1997). Planning and second language narrative production (Unpublished Doctoral dissertation). Temple University, Japan.

Wigglesworth, G. (1997). An investigation of planning time and proficiency level on oral test discourse. Language Testing, 14(1), 21-44. http://dx.doi.org/10.1177/026553229701400105

Willis, J. (1996). A framework for task-based learning. London: Longman.

Young, R., \& He, A. (1998). Talking and testing: Discourse approaches to the assessment of oral proficiency. Amsterdam: John Benjamins. http://dx.doi.org/10.1075/sibil.14

Yule, D., \& MacDonald, D. (1990). Resolving referential conflicts in L2 interaction: The effect of proficiency $\begin{array}{llll}\text { and interactive } \text { role. Language } & \text { Learning, }\end{array}$ http://dx.doi.org/10.1111/j.1467-1770.1990.tb00605.x

\section{Copyrights}

Copyright for this article is retained by the author(s), with first publication rights granted to the journal.

This is an open-access article distributed under the terms and conditions of the Creative Commons Attribution license (http://creativecommons.org/licenses/by/3.0/). 